\title{
The Suitability and the Bio-chemical Characteristics of Soils from the Northwest Region of Development from Romania, for Blueberry Crop
}

\author{
Amalia Ioana BOȚ ${ }^{1 *}$, Ioan PĂCURAR ${ }^{1}$, Lech SZAJDAK ${ }^{2}$, Sanda ROȘCA ${ }^{3}$ \\ ${ }^{1}$ Department of Soil and Technical Sciences, University of Agricultural Sciences and Veterinary Medicine, Mănăștur \\ Street, no. 3-5, 400372, Cluj-Napoca, Romania \\ ${ }^{2}$ Department of Environmental Chemistry, Institute of Agricultural and Forest Environment of Polish Academy of \\ Sciences, Bukowska Street, no. 19, 60-809, Poznan, Poland \\ ${ }^{3}$ Department of Geography, Babeș-Bolyai University, Clinicilor Street, no. 5-7, 400006, Cluj-Napoca, Romania \\ *corresponding author, e-mail: bot.amaliaioana@gmail.com
}

Bulletin USAMV series Agriculture 74(2)/2017

Print ISSN 1843-5246; Electronic ISSN 1843-5386

DOI 10.15835/buasvmcn-agr: 0007

\begin{abstract}
We conducted several bio-chemical analyses on soil samples collected from eight blueberry plantations from Northwest Region of Development, using such as Kjeldahl method for total N, Perucci, Krawczyński, Hoffman and Teicher methodology for determine soil enzyme. The bio-chemical analyses conducted provide a better qualitative characterization of soils, providing significant information regarding their fertility degree and favourability for blueberries. For instance, the higher amount of total organic carbon found in four of the eight studied plantation, can be correlated with the same higher amount of enzyme present in soil which have an influence on them, xanthine oxidase and peroxidase activity. Taking into account the requirements needed for a blueberry plantation, we demonstrate that organic soils have also had the highest amount of bio-chemical compounds, such as cambisoil, met in Galații Bistriței, where were also found the highest amounts of different forms of nitrogen $(1.755 \mathrm{~g} / \mathrm{kg}$ total $\mathrm{N} ; 0.0189 \mathrm{~g} / \mathrm{kg} \mathrm{NH}_{4}{ }^{+}$and $0.0231 \mathrm{~g} / \mathrm{kg} \mathrm{NO}_{3}$ in Galații Bistriței, comparing to $1.344 \mathrm{~g} / \mathrm{kg}$ of total nitrogen; $0.0126 \mathrm{~g} /$ $\mathrm{kg} \mathrm{NH}_{4}{ }^{+}$and $0.0119 \mathrm{~g} / \mathrm{kg} \mathrm{NO}_{3}{ }^{-}$in Ulmeni), different forms of carbon and the enzymes that influence this compounds in soil, xanthine oxidase activity, peroxidase activity and nitrate reductase activity.
\end{abstract}

Keywords: favourability, soil compounds, Vaccinium corymbosum

\section{INTRODUCTION}

There is a new interest of current population for the consumption of healthy food, rich in vitamins, minerals and other compounds beneficial to human health, such as polyphenols and flavonoids, with an high antioxidant potential (Mehvesh, 2013). Along with the increasing interest in a healthy diet, together with the environmental protection tendencies and the conservation of natural resources, these trends could ultimately lead into finding eco-friendly methods and techniques for plant cultivation and animal growth. Agriculture, especially organic farming, plays a double role in all this. On the one hand, it helps mitigate the effects of climate change by using crop technologies that do not destroy water reserves and soil resources and, on the other hand it offers the possibility of reintroducing into the agricultural circuit those varieties that were thought to be less productive.

Based on this aspects, the concept of determining land favorability for a certain crop plays a key role and offers the possibility to identify the most suitable land for any crop, being beneficial for local farmers, regional producers and other companies that can benefit from this 
technique, which can be very helpful in increasing yield in agriculture (Păcurar and Buta, 2010; Blaga et al., 2008).

Păcurar and Buta (2010) define the quality and the economic value of agricultural land as "the complex operation of in-depth knowledge of the conditions of growing and fruiting of plants and determining the degree of favorability of these conditions for different uses and crops (because a certain field may be favorable for some uses and cultures, but unfavorable for others) by means of an index of evaluation techniques and notes".

The economic value of agricultural land is determined by the relative value of land using the most appropriate and cost-effective crop techniques. Through this scientific approach, production levels and economic efficiency can be properly established (Spârchez, 2009).

It is clearly nowadays that farmers are looking for improving their cultivation techniques in order to obtain a higher yield, but also they are aware of the risks that come with intensive cultivation, for the environment and also for the human health. Hence, they focus now on crops and techniques that are environmental friendly and also, that bring a lot of benefits for human health and significant yield. Among these crops, berries are the most cultivated, such as blueberry, cranberry, strawberry, blackberry and raspberry.

Studies regarding the antioxidant capacity of berries have shown that among all berries, blueberries have the highest concentration of polyphenols and flavonoids, thus they have the highest antioxidant activity (Sona et al., 2015; Kazim et al., 2015; Charles et. al., 2012; Bunea et al., 2011). Of course, these values can be influenced by genotype, cultivation, irrigation systems and storage conditions (Cardenosa et al., 2016; Qi You et al., 2011).

Taking into account the benefits on human health that comes with the consumption of blueberries, such as improving the immune system, improves vision, lowers blood sugar and have beneficial effects for intestinal health (Krascovskaya, 2012; Stevenson and Scalzo, 2012), along with his high economic value given by the antioxidant properties (Diaconeasa et al., 2015), blueberry farming becomes more and more important nowadays and frequently used in almost each region of Romania.
The present paper work reveals the importance of understanding and knowing all processes that take place in soil, in order to make a better characterization of land, depending on the different crop that interests a farmer. According to Stevenson (1982), Lupașcu (1998), Magnof et al. (2004), Mihalache (2008) and Szajdak (2010), soil chemistry and biochemistry are the decisive factors for agriculture, no matter the crop, imputes and technology used. Besides these criteria, a major role plays the identification of favorability of land for a particular crop. In Romania, the identification of the degree of favorability of a region for a specific agricultural use is done according to the Methodological Norms developed by ICPA and OJSPA, volume I and II, 1987 and according to the Methodology of Pedological and Agrochemical Studies, of the National and County Monitoring Land-Soil System for Agriculture (Order No. 598 of August 13, 2002). Land evaluation mark system provides the proper information needed for knowing which type of soil is more suitable for a crop and less suitable for another. This evaluation helps farmers particularly when they want to establish a new crop in a location unknown for them or to change the use of land for different crop and culture.

For the studied area (Fig.1), this approach regarding the blueberry crop (Vaccinium corymbosum) is new in literature and provides valuable information. Along with the bio-chemical analyses conducted on soil, land evaluation and identifying the soil type from the studied area provide significant information regarding the qualitative properties of soil, taking into account the plant's requirements.

Overall, the results of this study will provide the basic information that is needed in order to establish a blueberry crop, knowing from ahead its requirements for soil, depending from one region to another, information that can be used for everyone who wants to start such crop. Due to the fact that blueberries compounds have extraordinary antioxidant properties, the economic value of this crop is also a major decisional point. In this case, the purpose of study is achieved by knowing which soil type is more favorable for blueberry crop, therefore which soil type will provide a better quality for fruits and greater income for the farmer. 

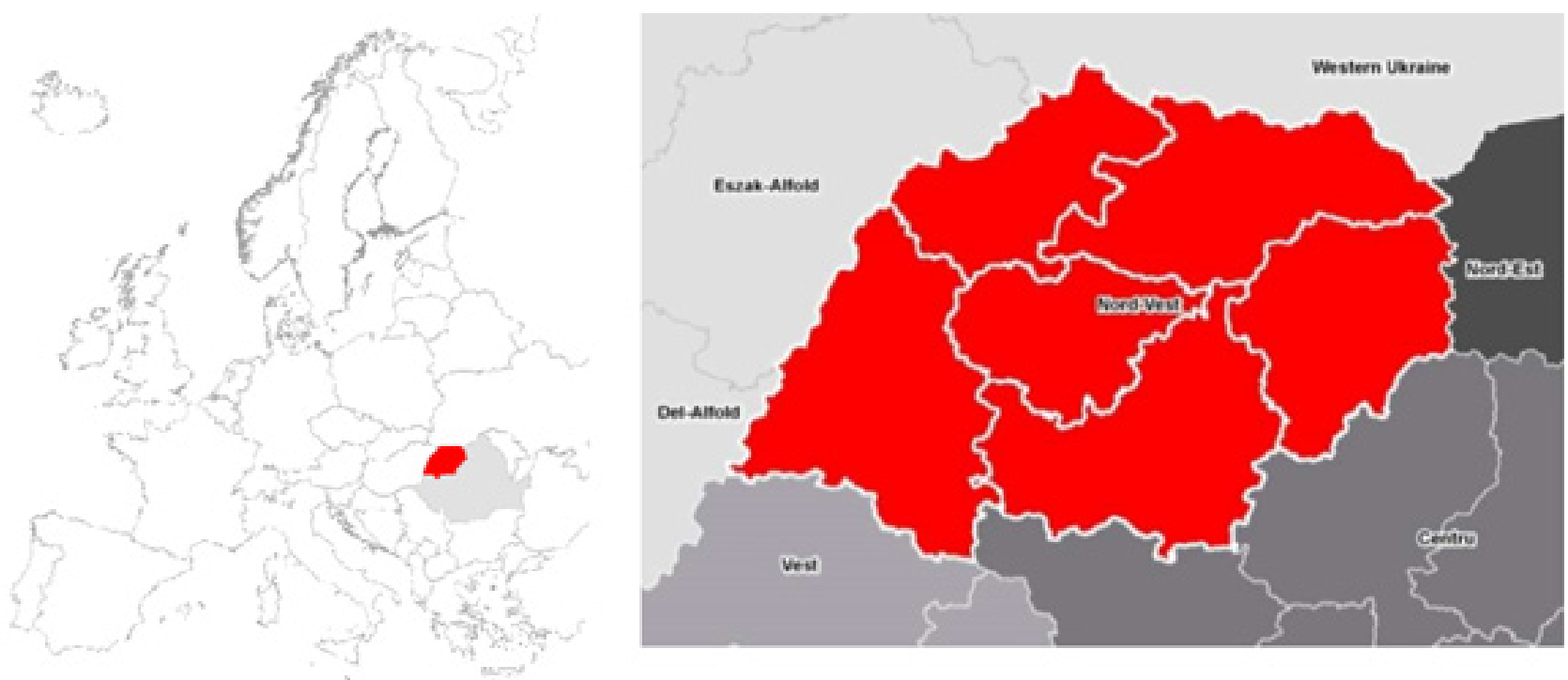

Fig. 1. Location of Northwest Region of Development in Romania (Source: http://www.nord-vest.ro/ wp-content/uploads/2016/09/7r238_PDR_2014_2020.pdf)

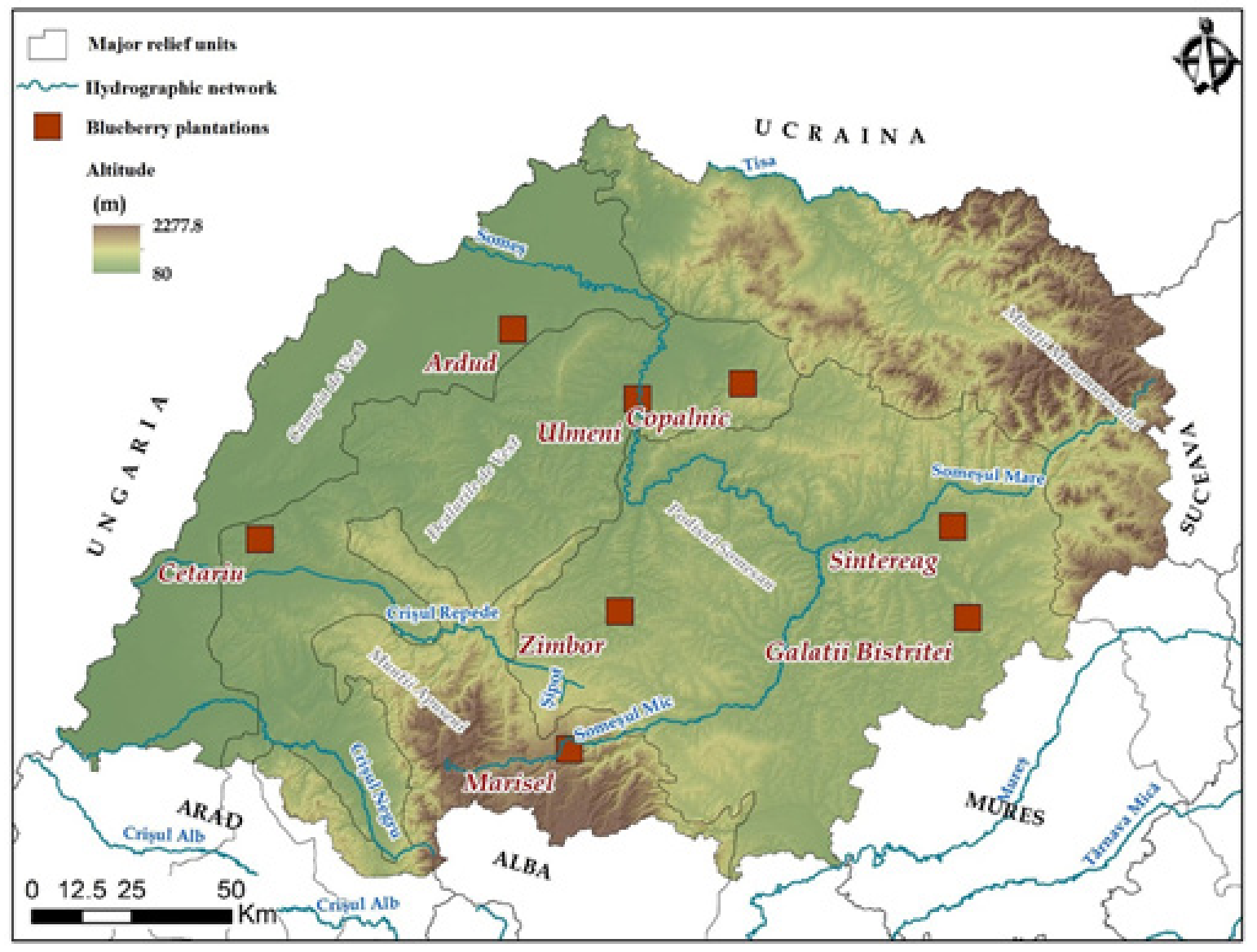

Fig. 2. Location of Northwest Region of Development in Romania 


\section{MATERIALS AND METHODS}

In order to assess the favorability of the studied area for blueberry crop, eight blueberry plantations were studied during the final year of doctoral studies, 2016-2017. First, their location were identified on the map of the Northwest Region of Development (Fig. 2) and then, based on GIS Spatial Analysis, soil type was identified for each plantation.

After identifying the soil type, in early spring of 2017, soil samples were collected from each of the eight plantation, as follows: one sample was collected from plantation (sample- A) and another sample was collected from 10 meters distance from plantation (control sample- B). A total of 16 samples were collected from all six counties of Northwest Region of Development and analyzed in the laboratories of the Institute of Agricultural and Forest Environment of Polish Academy of Sciences. The analysis conducted were: total nitrogen, ammonium and nitrates, total organic carbon and dissolved organic carbon, $\mathrm{pH}$ and soil enzymes, such as phenol oxidase activity, peroxidase activity, xanthine oxidase activity, urease activity and nitrate reductase activity, enzymes which are responsible for the amount of nutrients in soil and the humus content. This analyses provide a qualitative characterization of soils from each studied plantation.

\section{Applied methodology for soil analyses:}

$\boldsymbol{p H}$ was measured in $1 \mathrm{~N} \mathrm{KCl}$ and in water $(1: 20 \mathrm{v} / \mathrm{v})$ suspensions by potentiometric method. Soil bulk density was estimated from the soil organic matter concentration. The soil samples were dried at $105^{\circ} \mathrm{C}$ and ashed at $550^{\circ} \mathrm{C}$ using a muffle furnace. Bulk density was determined in soils mass per unit volume of soil. Porosity was calculated from the bulk density ratio of the soil to the density of solids. Density of solids was calculated from equation: $\mathrm{DS}=0.011 \mathrm{~A}+1.451$, where: DS - density of solids, A - ash content.

The total organic carbon (TOC) was analyzed on Total Organic Carbon Analyzer (TOC 5050A) with Solid Sample Module (SSM-5000A).

Dissolved organic carbon (DOC) was evaluated on TOC 5050A equipment. For the investigation of DOC, soil samples were heated in deionized water at $100^{\circ} \mathrm{C}$ for two hours under a reflux condenser. Extracts were filtered through $0.45 \mu \mathrm{m}$ poresize filters and analyzed on TOC 5050A facilities
(Smolander and Kitunen, 2002). Total nitrogen was evaluated by the Kjeldahl methods.

Ammonium ions were measured on ion chromatograph Waters 1515, equipped with a 1515 Isocratic HPLC pump, conductivity detector Waters 432, a rotary valve fitted with $20 \mu \mathrm{L}$ sample loop and column PRP-X200 (150 x 4.1 mm I.D.), protected with a guard column of the same material ( $25 \times 2.3 \mathrm{~mm}$ I.D.). Nitrate ions were determined on ion chromatograph HIC6A, equipped with a LP-6A Isocratic HPLC pump, conductivity detector CDD-6A, a rotary valve fitted with $20 \mu \mathrm{L}$ sample loop and column PRP-X100 ( $150 \times 4.1 \mathrm{~mm}$ I.D.) column protected with a guard column of the same material ( $25 \times 2.3 \mathrm{~mm}$ I.D.). Nitrate and ammonium ions as nitrogen were assayed in the same water extracts with an ion chromatograph (Szajdak et al., 2011b).

Urease activity was evaluated by Hoffmann and Teicher method (Szajdak et al., 2011). This method involves determination of the ammonium released by urease when soil is incubated with buffered $(\mathrm{pH}=6.7)$ urea solution and toluene at $37^{\circ} \mathrm{C}$ for $3 \mathrm{~h}$. The absorbance of the solution was measured colorimetrically at $\lambda_{\max }=630 \mathrm{~nm}$ using a UV-VIS spectrophotometer.

Xanthine oxidase activity was measured by Krawczyński method (Szajdak et al., 2011). Xanthine is used as a substrate for measurement of activity of the xanthine oxidase in fresh soil samples. The absorbance of the solution was measured colorimetrically at $\lambda_{\max }=290 \mathrm{~nm}$ using a UV-VIS spectrophotometer.

Phenol oxidase activity was determined by Perucci method (Szajdak et al., 2011). Catechol is used as a substrate for measurements of phenol oxidase activity in fresh soil samples. The absorbance of the solution was measured colorimerically at $\lambda_{\max }=525 \mathrm{~nm}$ using a UV-VIS spectrophotometer.

Peroxidase activity in soils was assayed by Bartha and Bordeleau method (Szajdak et al., 2011). Peroxidase activity was estimated by following the $\mathrm{H}_{2} \mathrm{O}_{2}$-mediated oxidation of $o$-dianisidine. The absorbance of the solution was measured colorimetrically at $\lambda_{\max }=460 \mathrm{~nm}$ using a UV-VIS spectrophotometer.

Nitrate reductase activity was determined using potassium nitrate as a substrate and 2,4-dinitrophenol as inhibitor of nitrite reductase according to Kandeler method. The field-moist 
soil samples were incubated for $24 \mathrm{~h}$ at $25^{\circ} \mathrm{C}$ under waterlogged conditions in test tubes. Nitrite released as a result of incubation was extracted with potassium chloride solution and determined colorimetrically at $\lambda_{\max }=520 \mathrm{~nm}$ (Szajdak et al., 2011).

\section{RESULTS AND DISCUSSIONS}

The analyses were conducted in order to determine the type of soil which is most suitable for a blueberry crop. For the different types of soils identified in the Northwest Region of Development of Romania, soil compounds were determined. The differences that occur from one plantation to another are due to different soil types, the technology for blueberry cultivation and the variety being the same for each plantation. Therefore, based on GIS technology, in the Northwest Region of Development, for the eight plantations that were took into study, the following identified soil type are related in Tab. 1.

Based on the requirements for blueberry crop, namely acidic and well-drained soil, rich in organic matter and moisture, with a $\mathrm{pH}$ between 4.5-5.5; multiannual temperatures between 7.8$8.5^{\circ} \mathrm{C}$ and over $700 \mathrm{~mm}$ rainfall (Clapa, 2006), soils located mostly in hilly area and piedmont, respectively location for a blueberry crop, are located in Mărișel, Șintereag, Cetariu, Copalnic and Zimbor.

The $\mathrm{pH}$ values for these locations highlighted in Tab. 1, the texture and the characteristics of soil class from these four plantations (Șintereag, Cetariu, Mărișel and Copalnic) have the better conditions for blueberry crop, from the soil type point of view and are the most suitable for such culture.

Tab. 1. Soil type of plantations studied from the Northwest Region of Development

\begin{tabular}{|c|c|c|c|c|c|c|}
\hline \multirow{9}{*}{ 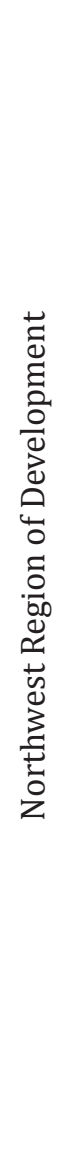 } & Counties & Location of plantation & Soil class & Soil type ${ }^{1}$ & Texture & $\mathrm{pH}$ \\
\hline & \multirow{2}{*}{$\begin{array}{l}\text { Bistrița- } \\
\text { Năsăud }\end{array}$} & $\begin{array}{c}\text { Galații Bistriței } \\
\left(46^{\circ} 59^{\prime} 47^{\prime \prime} \mathrm{N} \text { and }\right. \\
\left.24^{\circ} 24^{\prime} 39^{\prime \prime} \mathrm{E}\right) \\
\end{array}$ & Cambisoil & Eutricambosoil & Silt loam & 7.0 \\
\hline & & $\begin{array}{c}\text { Sintereag } \\
\left(47^{\circ} 12^{\prime} 11^{\prime \prime N} \text { and }\right. \\
\left.24^{\circ} 31^{\prime} 36^{\prime \prime} \mathrm{E}\right) \\
\end{array}$ & Luvisoil & $\begin{array}{l}\text { Typically luvosil and } \\
\text { pseudogleizat luvosoil }\end{array}$ & Sandy loam & 5.0 \\
\hline & Bihor & $\begin{array}{c}\text { Cetariu } \\
\left(47^{\circ} 08^{\prime} 22^{\prime \prime} \mathrm{N} \text { and }\right. \\
\left.22^{\circ} 04^{\prime} 05^{\prime \prime} \mathrm{E}\right) \\
\end{array}$ & Luvisoil & Typical brown luvosoil & Clayey & 5.4 \\
\hline & Cluj & $\begin{array}{c}\text { Mărișel } \\
\left(46^{\circ} 41^{\prime} 08^{\prime \prime} \mathrm{N} \text { and }\right. \\
\left.23^{\circ} 06^{\prime} 28^{\prime \prime} \mathrm{E}\right) \\
\end{array}$ & Cambisoil & Districambosoil & Sandy loam & 4.9 \\
\hline & \multirow{2}{*}{ Maramureș } & $\begin{array}{c}\text { Ulmeni } \\
\left(47^{\circ} 28^{\prime} 50^{\prime \prime} \mathrm{N} \text { and }\right. \\
\left.23^{\circ} 18^{\prime} 21^{\prime \prime} \mathrm{E}\right)\end{array}$ & Cambisoil & Eutricambosoil & $\begin{array}{l}\text { Varied } \\
\text { texture }\end{array}$ & 6.1 \\
\hline & & $\begin{array}{c}\text { Copalnic } \\
\left(47^{\circ} 31^{\prime} 09^{\prime \prime} \mathrm{N} \text { and }\right. \\
\left.23^{\circ} 39^{\prime} 19^{\prime \prime} \mathrm{E}\right)\end{array}$ & Luvisoil & Typical brown luvosoil & Clay & 5.0 \\
\hline & Satu Mare & $\begin{array}{c}\text { Ardud } \\
\left(47^{\circ} 37^{\prime} 53^{\prime \prime} \mathrm{N} \text { and }\right. \\
\left.22^{\circ} 53^{\prime} 04^{\prime \prime}\right)\end{array}$ & Luvisoil & Typical luvosoil & Clayey & 6.6 \\
\hline & Sălaj & $\begin{array}{c}\text { Zimbor } \\
\left(46^{\circ} 59^{\prime} 57^{\prime \prime N} \text { and }\right. \\
\left.23^{\circ} 15^{\prime} 47^{\prime \prime} \mathrm{E}\right)\end{array}$ & Cernisoil & Brown rendzinic & $\begin{array}{l}\text { Clayey and } \\
\text { silty-clay }\end{array}$ & 6.4 \\
\hline
\end{tabular}

\footnotetext{
${ }^{1}$ Soil type are accordingly to Romanian Soil taxonomy System, Florea and Munteanu, 2012
} 
Tab. 2. The amount ${ }^{*}$ of compounds from soil

\begin{tabular}{cccccc}
\hline Plantation & Total $\mathrm{N}$ & $\mathrm{NH}_{4}{ }^{+}$ & $\mathrm{NO}_{3}{ }^{-}$ & $\mathrm{TOC}$ & $\mathrm{DOC}$ \\
\hline Galații Bistriței & $\mathbf{1 . 7 5 5} \pm \mathbf{0 . 4 6 3 7 4}$ & $\mathbf{0 . 0 1 8 9} \pm \mathbf{0 . 0 0 0 4}$ & $\mathbf{0 . 0 2 3 1} \pm \mathbf{0 . 0 0 0 6}$ & $26.40 \pm 1.21$ & $\mathbf{2 . 0 6} \pm \mathbf{0 . 2 3}$ \\
\hline Șintereag & $\mathbf{1 . 6 8 0} \pm \mathbf{0 . 2 4 0 9 7}$ & $0.0112 \pm 0.0006$ & $\mathbf{0 . 0 1 9 6} \pm \mathbf{0 . 0 0 0 3}$ & $\mathbf{2 8 . 3 6} \pm \mathbf{0 . 9 8}$ & $1.25 \pm 0.23$ \\
\hline Cetariu & $0.896 \pm 0.24097$ & $0.0147 \pm 0.0007$ & $0.0063 \pm 0.0001$ & $9.32 \pm 0.48$ & $0.80 \pm 0.14$ \\
\hline Mărișel & $1.755 \pm 0.09275$ & $0.0147 \pm 0.0004$ & $0.0126 \pm 0.0005$ & $37.62 \pm 0.77$ & $2.79 \pm 0.06$ \\
\hline Ulmeni & $1.344 \pm 0.24097$ & $0.0126 \pm 0.0004$ & $0.0119 \pm 0.0003$ & $19.85 \pm 0.33$ & $1.19 \pm 0.08$ \\
\hline Copalnic & $1.475 \pm 0.04637$ & $0.0133 \pm 0.0003$ & $\mathbf{0 . 0 3 0 8} \pm \mathbf{0 . 0 0 1 9}$ & $21.83 \pm 1.14$ & $1.22 \pm 0.03$ \\
\hline Ardud & $\mathbf{1 . 6 2 4} \pm \mathbf{0 . 2 7 8 2 5}$ & $\mathbf{0 . 0 1 4 7} \pm \mathbf{0 . 0 0 0 5}$ & $0.0091 \pm 0.0004$ & $\mathbf{2 6 . 4 8} \pm \mathbf{0 . 3 8}$ & $\mathbf{1 . 4 0} \pm \mathbf{0 . 0 0}$ \\
\hline Zimbor & $0.849 \pm 0.02319$ & $\mathbf{0 . 0 1 9 0} \pm \mathbf{0 . 0 0 0 7}$ & $0.0293 \pm 0.0017$ & $\mathbf{3 3 . 9 4} \pm \mathbf{1 . 0 2}$ & $\mathbf{5 . 1 6} \pm \mathbf{0 . 2 0}$ \\
\hline
\end{tabular}

${ }^{*}$ the amount of compounds is expressed in $\mathrm{g} / \mathrm{kg}$

Tab. 3. The enzymatic activity

\begin{tabular}{cccccc}
\hline Plantation & $\begin{array}{c}\text { Phenol oxidase } \\
\text { activity } \\
\left(\mu \mathrm{mol} \cdot \mathrm{h}^{-1} \cdot \mathrm{g}^{-1}\right)\end{array}$ & $\begin{array}{c}\text { Peroxidase } \\
\text { activity } \\
\left(\mathrm{nmol} \cdot \mathrm{h}^{-1} \cdot \mathrm{g}^{-1}\right)\end{array}$ & $\begin{array}{c}\text { Xanthine oxidase } \\
\text { activity } \\
\left(\mu \mathrm{mol} \cdot \mathrm{h}^{-1} \cdot \mathrm{g}^{-1}\right)\end{array}$ & $\begin{array}{c}\text { Urease activity } \\
\left(\mu \mathrm{mol} \cdot \mathrm{h}^{-1} \cdot \mathrm{g}^{-1}\right)\end{array}$ & $\begin{array}{c}\text { Nitrate reductase } \\
\text { activity } \\
\left(\mu \mathrm{g} \mathrm{N} \cdot \mathrm{g}^{-1}\right)\end{array}$ \\
\hline $\begin{array}{c}\text { Galații } \\
\text { Bistriței }\end{array}$ & $\mathbf{2 5 . 3 1 5} \pm \mathbf{3 . 1 1 7}$ & $\mathbf{0 . 0 0 2 3} \pm \mathbf{0 . 0 0 0 2}$ & $4.435 \pm 0.457$ & $\mathbf{3 . 2 3 3} \pm \mathbf{0 . 5 1 1}$ & $\mathbf{0 . 1 7 6} \pm \mathbf{0 . 0 2 6}$ \\
\hline Șintereag & $8.344 \pm 0.734$ & $0.0006 \pm 0.0001$ & $4.667 \pm 0.387$ & $1.276 \pm 0.261$ & $0.138 \pm 0.026$ \\
\hline Cetariu & $13.430 \pm 2.116$ & $0.0006 \pm 0.0001$ & $4.487 \pm 0.306$ & $1.408 \pm 0.041$ & $0.067 \pm 0.012$ \\
\hline Mărișel & $13.946 \pm 1.823$ & $\mathbf{0 . 0 0 1 2} \pm \mathbf{0 . 0 0 0 0}$ & $\mathbf{4 . 9 6 3} \pm \mathbf{0 . 1 6 0}$ & $\mathbf{2 . 9 7 7} \pm \mathbf{0 . 1 2 4}$ & $0.095 \pm 0.012$ \\
\hline Ulmeni & $\mathbf{1 5 . 3 2 1} \pm \mathbf{4 . 8 2 1}$ & $\mathbf{0 . 0 0 1 3} \pm \mathbf{0 . 0 0 0 1}$ & $\mathbf{4 . 8 0 2} \pm \mathbf{0 . 1 4 5}$ & $0.720 \pm 0.072$ & $\mathbf{0 . 2 9 9} \pm \mathbf{0 . 0 6 4}$ \\
\hline Copalnic & $12.693 \pm 1.869$ & $0.0005 \pm 0.0000$ & $\mathbf{5 . 1 1 0} \pm \mathbf{0 . 4 0 9}$ & $\mathbf{1 . 4 8 8} \pm \mathbf{0 . 2 8 8}$ & $0.055 \pm 0.012$ \\
\hline Ardud & $\mathbf{1 4 . 8 4 0} \pm \mathbf{2 . 2 0 4}$ & $0.0006 \pm 0.0000$ & $\mathbf{4 . 8 8 6} \pm \mathbf{0 . 5 1 9}$ & $1.392 \pm 0.144$ & $\mathbf{0 . 2 0 1} \pm \mathbf{0 . 0 1 9}$ \\
\hline Zimbor & $\mathbf{1 4 . 7 7 0} \pm \mathbf{1 . 4 6 5}$ & $\mathbf{0 . 0 0 1 3} \pm \mathbf{0 . 0 0 0 0}$ & $4.578 \pm 0.377$ & $\mathbf{2 . 5 4 5} \pm \mathbf{0 . 4 0 1}$ & $\mathbf{1 . 0 1 8} \pm \mathbf{0 . 1 1 7}$ \\
\hline
\end{tabular}

Furthermore, we identified the amount of different compounds from the soil samples taken from plantations (total nitrogen, ammonium, nitrate, total organic carbon (TOC) and dissolved organic carbon (DOC)) presented in Tab. 2, and the enzymatic activity for phenol oxidase activity, peroxidase activity, xanthine oxidase activity, urease activity, nitrate reductase activity, as shown in Tab. 3.

Regarding the differences between plantation, from the graphic bellow (Fig. 3) we can state out that, regarding the level of nutritive compounds in soil, the best locations for a blueberry crop from the amount of organic matter point of view, are in Mărișel and Zimbor, followed closely by Șintereag,
Galații Bistriței and Ardud. Talking about the amount of nitrogen, the results are quite similar for all plantations, with higher amounts in Galații Bistriței and Mărișel (Tab. 2), for both organic and inorganic forms.

The reason why the amount of organic matter is different from a location to another states that different types of soil have different biochemical characteristics, different texture and $\mathrm{pH}$, which have a significant influence on the results obtained. Another factor that could influence our results is the plantation technique that farmers used. When they established the culture, they had to use a mix of soil, sawdust and peat moss in different quantities, depending on soil type and 


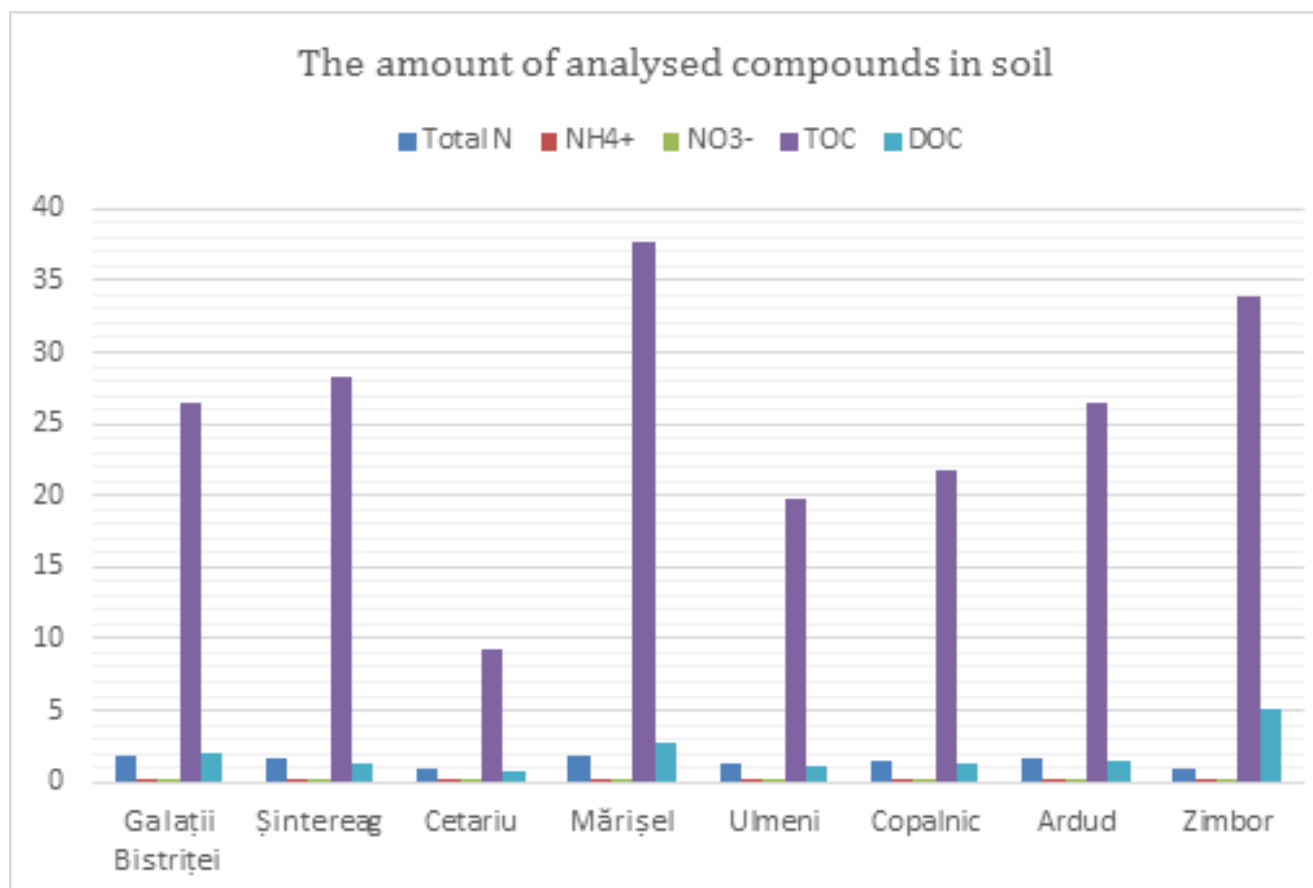

Fig. 3. The amount of different compounds in soil

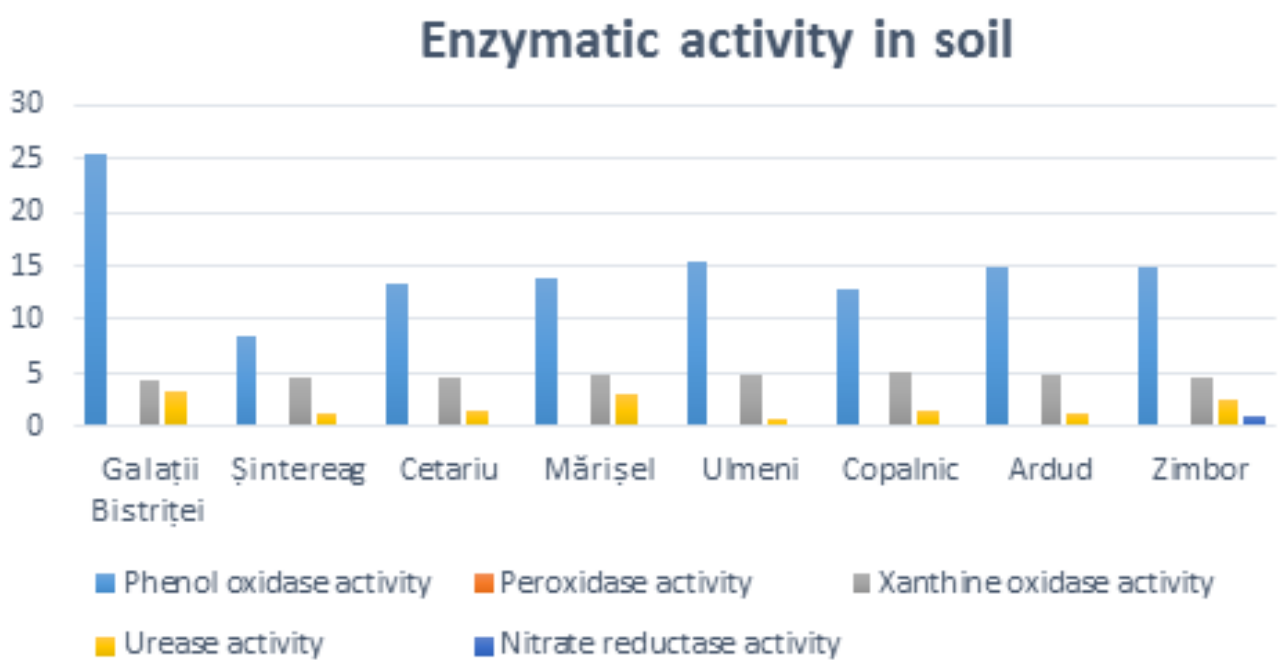

Fig. 4. The activity of different enzymes in soil

texture. This three components mixed together are a general and the most important condition for establishing a blueberry crop.

For the enzymatic activity in soil, we observed that the presence of phenol oxidase activity and xanthine oxidase activity is higher than other enzymes, as noted in graphic bellow. These results can also be explained by noticing the different soil types identified above and also we have to consider the presence of peat moss and sawdust in soil, organic amendments that were used for blueberry crop, which improve aeration of soil, texture and the amount of organic matter. 
Tab. 4. Best locations for blueberry crop, from the bio-chemical compounds point of view

\begin{tabular}{|c|c|c|c|c|c|c|c|c|}
\hline $\begin{array}{l}\text { Plantation/ } \\
\text { Bio-chemical analyse }\end{array}$ & Șintereag & $\begin{array}{c}\text { Galații } \\
\text { Bistriței }\end{array}$ & Cetariu & Mărișel & Ulmeni & Copalnic & Ardud & Zimbor \\
\hline Total N & $\mathrm{X}$ & $\mathrm{X}$ & & $\mathrm{X}$ & & & $\mathrm{X}$ & \\
\hline $\mathrm{NH}_{4}^{+}$ & & $\mathrm{X}$ & & $\mathrm{X}$ & & & & $\mathrm{X}$ \\
\hline $\mathrm{NO}_{3}^{-}$ & & $\mathrm{X}$ & & $\mathrm{X}$ & & & & $\mathbf{X}$ \\
\hline TOC & $\mathrm{X}$ & $\mathrm{X}$ & & $\mathrm{X}$ & & & & $\mathrm{X}$ \\
\hline DOC & $\mathbf{X}$ & $\mathbf{X}$ & & $\mathrm{X}$ & & & & $\mathrm{X}$ \\
\hline $\begin{array}{l}\text { Phenol oxidase } \\
\text { activity }\end{array}$ & & $\mathrm{X}$ & & & $\mathrm{X}$ & & $\mathbf{X}$ & $\mathbf{X}$ \\
\hline Peroxidase activity & & $\mathrm{X}$ & & $\mathrm{X}$ & $\mathrm{X}$ & & & $\mathrm{X}$ \\
\hline $\begin{array}{l}\text { Xanthine oxidase } \\
\text { activity }\end{array}$ & & & & $\mathrm{x}$ & $\mathrm{x}$ & $\mathrm{X}$ & $\mathrm{x}$ & \\
\hline Urease activity & & $\mathrm{X}$ & & $\mathrm{X}$ & & $\mathrm{X}$ & & $\mathrm{X}$ \\
\hline $\begin{array}{l}\text { Nitrate reductase } \\
\text { activity }\end{array}$ & & $\mathrm{x}$ & & & $\mathrm{x}$ & & $\mathrm{x}$ & $\mathrm{x}$ \\
\hline
\end{tabular}

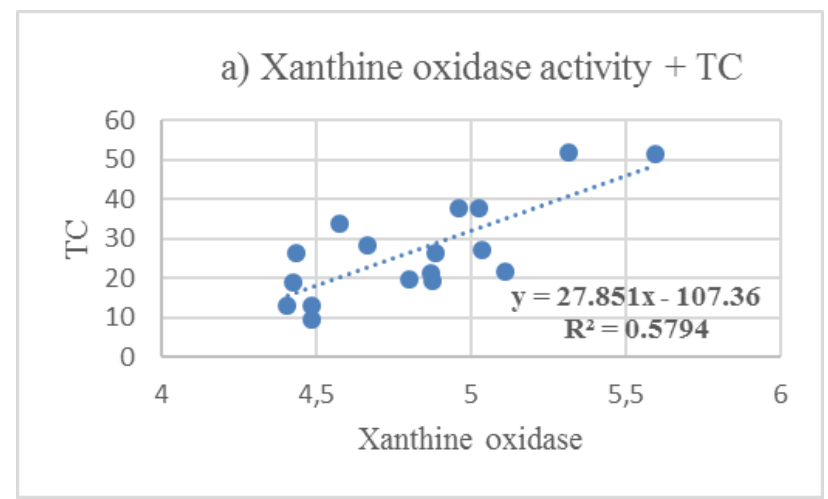

c) Nitrate reductase $+\mathrm{NH} 4$

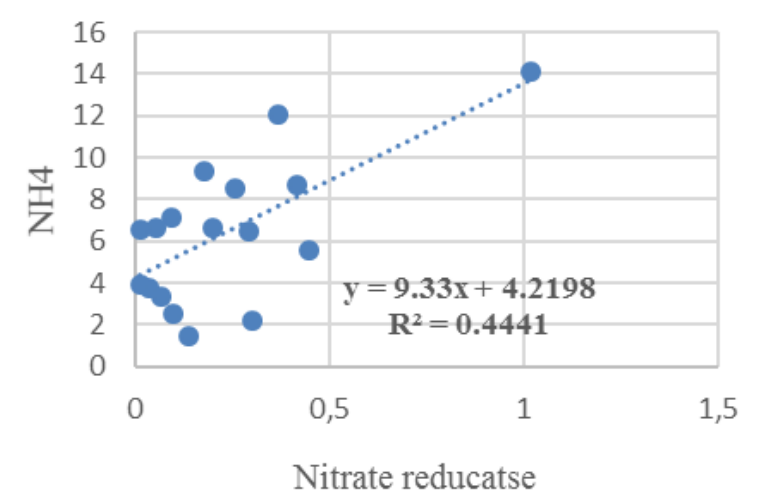

b) Peroxidase $+\mathrm{TC}$

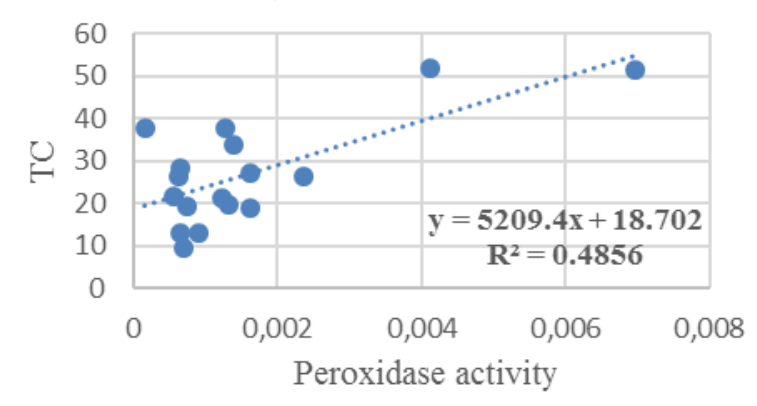

d) Nitrate reductase $+\mathrm{NO} 3$

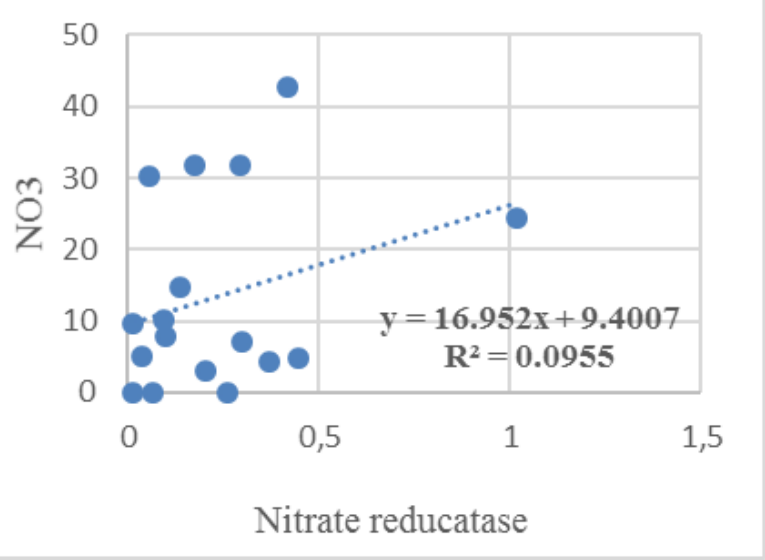

Fig. 5. Significant positive correlation of enzymatic activity and some compounds in soil (Microsoft ExcelData Analysis- Correlation, for alpha $=.05$ ) between: a) xanthine oxidase activity and the amount of total carbon; b) peroxidase activity and the amount of total carbon; c) nitrate reductase activity and the amount of ammonium ions of nitrogen; d) nitrate reductase activity and the amount of nitrate ions of nitrogen 
Based on the data obtain, the best location for a blueberry crop from the eight plantations studied in the research, regarding their biochemical characteristics are noted in Table 4.

Total nitrogen is converted in the mineral forms available for plants, especially $\mathrm{NH}_{4}+$, by urease activity and phenol oxidase activity. The second graphic (Fig. 4), shows that the higher activity of this enzymes is also met in the same location where the amount of total nitrogen was higher. Not only the graphics and data show the influence of enzyme on some compounds in soil, but also using Pearson correlation for two variable data, we can state the same results (Fig. 5).

\section{CONCLUSIONS}

Based on the analysis conducted on soils and on the identification of the type of soil from each location, we concluded the following: from the soil type point of view, the best location for blueberry crop are those from Mărișel, Șintereag, Cetariu, Copalnic and Zimbor, because the natural characteristics of this soils provide better conditions for this culture. Then, when talking about content of different compounds, Galații Bistriței, Mărișel and Zimbor meet the most suitable conditions: higher amount of organic matter and total nitrogen.

Taking into account the requirements of blueberry crop for soil, the analyses conducted revealed the fact that different soil type give different soil characteristics, from the compounds point of view and the enzymatic activity that influence them. Generally, organic soils or soils with good texture and content of organic matter, meet the highest values of bio-chemical compounds from soil.

Overall, based on all factors analyzed in this research, such as soil type, texture, $\mathrm{pH}$, biochemical compounds and the requirements for the culture of blueberry, we can state the fact that the best conditions, from the eight plantation studied, are met in Mărișel and Galații Bistriței.

\section{REFERENCES}

1. Blaga G, Paulette L, Udrescu S, Filipov F, Rusu I, Vasile D (2008). Pedologie, Editura Mega, Cluj-Napoca.

2. Bunea A, Rugină OD, Pintea AM, Sconța Z, Bunea CI, Socaciu C (2011). Comparative Polyphenolic Content and Antioxidant Activities of Some Wild and Cultivated Blueberries from Romania. Not Bot Horti Agrobo, 39(2):70-76;
3. Burns RG (1978). Soil enzymes, Academic Press, London.

4. Cardeñosa V, Girones-Vilaplana A, Muriel JL, Moreno DA, Moreno-Rojas J (2016). Influence of genotype, cultivation system and irrigation regime on antioxidant capacity and selected phenolic of blueberries Vaccinium corymbosum L.). Food Chemistry, 202:276-283.

5. Charles FF, Wilhelmina K., Michael AJ, Vinqvist-Tymchu MR, and Fillmore AE (2012). Blueberry and cranberry fruit composition during development. Journal of Berry Research, 2:169-177, DOI:10.3233/JBR-2012-034.

6. Clapa D (2006). Micropropagarea afinului cu tufă înaltă (Vaccinium corymbosum)- o soluție rapidă pentru valorificarea solurilor acide. Agricultură - Știință și practică, 1-2: 57-58.

7. Diaconeasa Z, Leopold L, Rugină D, Ayvaz H, Socaciu C (2015). Antiproliferative and Antioxidant Properties of Anthocyanin Rich Extracts from Blueberry and Blackcurrant Juice, International Journal of Molecular Sciences, 12:125-138.

8. Florea N, Munteanu I (2012). Sistemul Român de Taxonomie a Solurilor (SRTS), ICPA București.

9. Kazim G, Sedat S, Hancock JF, (2015). Variation among highbush and rabbiteye cultivars of blueberry for fruit and phytochemical characteristics. Journal of Food Composition and Analysis, 38:69-79.

10. Lupașcu G (1998). Curs de geografia solurilor cu elemente de pedologie. Editura Universității Universității Al. I. Cuza, Iași.

11. Magnoff F, Weil R (2004). Soil organic matter in sustainable agriculture. CRC Press, USA.

12. Mehvesh M, Wani SM, (2013). Polyphenols and human health - A Review, International Journal of Pharma and Bio Sciences. Int J Pharm Bio Sci, 4(2):(B) 338 - 360;

13. Mihalache M, Ilie L (2008). Pedologie-Solurile României. Ed. Dominor, București.

14. Păcurar I, Buta M (2010). Pedologie și bonitarea terenurilor agricole - Lucrări practice. Ed. AcademicPres Cluj-Napoca.

15. Qi Y, Baowu W, Feng C, Zhiliang H, Xi W, Pengju GL (2011). Comparison of anthocyanins and phenolics in organically and conventionally grown blueberries in selected cultivars. Food Chemistry, 125:201-208.

16. Skrovankova S, Sumczynski D, Mlcek J, Jurikova T, Sochor J (2015). Bioactive compounds and Antioxidant Activity in Different Types of Berries Int. J. Mol. Sci., 16:2467324706, doi:10.3390/ijms161024673.

17. Smolander A, Kitunen V, Malkonen E (2002). Disolved soil organic nitrogen and carbon in a Norway spruce stand and an adjacent clear-cut. Biology and Fertility of Soils, 33:90-196.

18. Spârchez G (2009). Cartarea și bonitarea terenurilor agricole și silvice. Tipografia Universității Brașov.

19. Stevenson FJ (1982). Humus chmestry- genesis, composition, reactions. John Wiley\&Sons, USA.

20. Szajdak LW, Meysner T, Styła K (2011). Biochemical and chemical characterization of soils under shelterbelts and adjoining cultivated fields. In: Szajdak LW (Ed.). Shalterbelts: efficient element of the landscape. Chemical 
and biochemical investigations of ground water and soil. LAP Lambert Academic Publishing. Saarbrücken, Germany, 33-53.

21. Szajdak LW, Karabanov AK, (2010). Phisical, chemical and biochemical processes in soils. Institute for Agricultural and Forest Environment, Polish Academy of Sciences, Poznan.

22. Velioglu YS, Mazza G, Gao L, Oomah B (2016). Antioxidant activity and total phenolics in selected fruits, vegetables and grain products. Journal of Agricultural and Food Chemistry, 28: 435-450.

23. ***Ordin nr 598 din 13 August, (2002). MODUL din 28 mai 2002 de finantare a studiilor pedologice si agrochimice si a Sistemului national si judetean de monitorizare solteren pentru agricultura.

24. ***http : / / w w w.nord-vest.ro/wp-content/ uploads/2016/09/7r238_PDR_2014_2020.pdf. 